\title{
Seasonal Variation of Nutritional Intake from 24-Hour Urine Collection and Adherence in Patients with Chronic Kidney Disease
}

Rie Onda ${ }^{1}$, Yume Nagaoka², Yoshitaka Miyaoka ${ }^{2}$, Tomonari Okada ${ }^{2}$, Asako Gondo ${ }^{2}$, Miho Nagai $^{2}$, Eiichiro Kanda ${ }^{3}$, Yoshihiko Kanno ${ }^{2}$

${ }^{1}$ Department of Clinical Nutrition and Dietetics, Kagawa Nutrition University, Sakado, Japan

${ }^{2}$ Department of Nephrology, Tokyo Medical University, Japan

${ }^{3}$ Medical Science, Kawasaki Medical School, Okayama, Japan

Received: 18 November, 2019; Accepted: 28 December, 2019; Published: 7 January, 2020

*Corresponding author: Yoshihiko kanno, Department of Nephrology, Tokyo Medical University, 6-7-1 Nish iShinjuku, Shinjuku, Tokyo 1600023, Japan, Tel: +81-33342-6111 exe.5000, E-mail: kannoyh@tokyo-med.ac.jp

\begin{abstract}
Background: For appropriate diet therapy, it is desirable to determine urine volume and excreted urinary components using 24-hour urine volume (24hUV) and compare these data with indications. $24 \mathrm{hUV}$ allows an accurate measurement of excreted urinary protein, glucose, and salt per day, which are important for assessment of renal function and diet intake. In particular, urine volume may be seasonal variations because of the effect of perspiration.
\end{abstract}

Methods: The subjects were 37 (29 males and 8 females) outpatients with chronic kidney disease (CKD) who underwent 24-hour urine collection and were given nutrition education (consultation) continuously for 2 years or more. The survey period was January 2012 to July 2014. Patients were divided into 3groups according to their adherence to indicated intake as A, $<15 \%$ difference, B, $\geq 15 \%$.

Results: There was no significant difference in $24 \mathrm{hUV}$ and urinalysis between seasons. Mean Na throughout the year was $82 \pm 29 \mathrm{mEq} / \mathrm{L}$, and Mean K throughout the year was $20.4 \pm 9.4 \mathrm{mEq} / \mathrm{L}$. Estimated protein and salt intake were lower in group A throughout the year.

Conclusion: Urine $24 \mathrm{hUV}$ and urinalysis were not influenced by seasonal variations, and these findings were due to the influence of diet intake.

Key Word: diet therapy; estimated intake; protein; salt; energy

\section{Introduction}

Protein intake restriction is widely used in patients with renal impairment as therapy for inhibiting disease progression. A low-protein diet inhibits progression of renal impairment and introduction of dialysis through relief of uremia and release from Glomerular hyper filtration $[1,2]$. Effects of renin-angiotensin system inhibitors, sodium bicarbonate and phosphorus adsorbents have also been found and these drugs are widely used; however, protein intake restriction remains important, and is described and recommended in worldwide and Japanese guidelines [3]. Salt intake restriction is involved in prevention of hypertension and cardiovascular disease in patients with Chronic Kidney Disease (CKD). In patients with chronic nephritis and diabetic nephropathy, salt intake correlates with excreted urine protein, and salt intake restriction has been suggested to degrade progression of nephropathy [4].

Given the above findings, it is important for patients with CKD to have a diet that focuses on protein and salt intake restriction. For appropriate diet therapy, it is desirable to determine urine volume and excreted urinary components using 24-hour urine volume (24hUV) and compare these data with indications [5]. Such assessment and estimation using spot urine is possible, but most urinary components increase during the day and decrease at night, and are influenced by diet, posture and movement. Kawasaki et, al. examined salt intake using spot urine, and found that the $\mathrm{T}$ method was most accurate for estimating excreted urinary sodium using urine during a hospital visit. However, the difference between estimation of excreted urinary sodium and salt intake exceeding $2 \mathrm{~g} /$ day was $45 \%$ in all tests, which indicates a problem obtaining accurate data [6]. In contrast, $24 \mathrm{hUV}$ allows an accurate measurement of excreted urine volume, urine protein and urine glucose per day, which are important for accurate assessment of renal function and diet intake [7]. However, $24 \mathrm{hUV}$ may be a cause of nosocomial infection and many specialists do not use this approach because of an increased burden on patients $[8,9]$.

Estimation of dietary intake is limited because salt intake per day cannot be accurately determined due to acute changes in salt intake, severe diarrhea and vomiting, and the start or discontinuation of diuretics. Spot $24 \mathrm{hUV}$ in healthy subjects has been shown not to match mean daily sodium excretion [10]. In particular, urine volume depends on perspiration volume and there may be seasonal variations in urine volume [11]. Few studies have examined the relationship of $24 \mathrm{hUV}$ with seasonal 
variations in patients with CKD, but accurate assessment through improvement of the accuracy of $24 \mathrm{hUV}$ test is necessary to establish appropriate diet therapy in these patients.

\section{Methods}

The subjects were male and female outpatients with CKD who underwent 24-hour urine collection and were given nutrition education (consultation) continuously for 2 years or more. The survey period was 2 months from July to August 2014 and clinical data were obtained from medical records of 201 patients $(127$ males and 74 females) for 2 years from January 2012 to July 2014. Of these patients, the subjects in the final analysis were 37 patients ( 29 males and 8 females) with data for four seasons from January 2012 to July 2014.

Sex, age, height, body weight, systolic blood pressure (SBP) and diastolic blood pressure (DBP) were collected on the survey, and primary disease, complications, diuretics and prescription data were obtained from clinical records. Body mass index (BMI) was calculated from height and body weight. Blood and urine data determined at the beginning of the survey in July 2014 were also taken from clinical records. The hematological and biochemical test data included Red Blood Cell Count (RBC), Hemoglobin (Hb), Hematocrit (Ht), White Blood Cell Count (WBC), Platelet Count (Plt), Total Protein (TP), Serum Albumin (Alb), Total Cholesterol (TC), Low-Density Lipoprotein Cholesterol (LDL-C), Fasting Plasma Glucose (FPG), Gamma-Glutamyl Transpeptidase ( $\gamma$-GTP), Blood Urea Nitrogen (BUN), Serum Creatinine (Cr), Uric Acid (UA), Estimated Glomerular Filtration Rate (eGFR), Serum Sodium (Na), Serum Potassium (K), Calcium (Ca), Serum Inorganic Phosphorus (P), Voluntary Cr (Spot Urine), and Urine Protein (UP) (spot urine).

Blood pressure, hematology, urine volume and urinalysis data from January 2012 to July 2014 were obtained from clinical records. These data included SBP, DBP, WBC, TP, Alb, BUN, Cr, UA, TC, triglyceride (TG), hemoglobin A1c using the National Glycohemoglobin Standardization Program (HbA1c (NGSP)), Na, $\mathrm{K}, \mathrm{Ca}$ and $\mathrm{P}$. The urine data included 24hUV, UP, urea nitrogen (UN), Cr, UA, Na, K and P.

Indicated energy per day (E: kcal), E intake (kcal), E assessment, indicated protein (Pro: g), Pro intake (g), Pro assessment, indicated salt ( $\mathrm{NaCl}: \mathrm{g}), \mathrm{NaCl}$ intake (g) and $\mathrm{NaCl}$ assessment were obtained from nutrition education records. E, Pro and $\mathrm{NaCl}$ were assessed from the difference between the indication and intake, with groups defined based on this difference as A, <15\%; B, $\geq 15 \%$. Patients in group A had good adherence to diet and those in group $\mathrm{BC}$ had poorer adherence.

Nutrition education was offered as close as possible to tests for blood pressure, hematology, urine volume and urinalysis within the same season. Four seasons were chosen before July 2014, the date of the survey. The classification of seasons referred to the website of the Japan Meteorological Agency: 3 months (July to September) with a high mean temperature in 2012 and 2013 were defined as summer, 3 months (December to February) with a low temperature were defined as winter, and then March to June was defined as spring, and October to November as autumn [12].

Characteristics of patients and test results for blood pressure, hematology, urine volume and urinalysis are shown as mean \pm standard deviation or with a range (minimum to maximum). The number and percentage of patients for primary disease, complications and prescribed diuretics are shown in cross tabulations. Statistical analysis was performed using "4 Step Excel Statistics" (OMS publishing Inc.). Results for blood pressure, hematology, 24hUV and urinalysis by season were analyzed by one-way analysis of variance, Kruskal-Wallis test and multiple comparisons. The same results and adherence to the indicated diet were analyzed by two-way analysis of variance for repeated measures. Differences in test results by adherence were analyzed by $\mathrm{F}$ test. The significance level was $5 \%$ in all statistical tests.

This study was approved by the research ethics committee of Tokyo Medical University (No. 2716, June 3, 2014). Patients were informed by attending physicians that information in clinical records could be used in a study. Information was posted in the outpatient department stating that patients could exclude themselves from the study based on their decision or that of their family. The study results are presented as tables with elimination of personal information.

\section{Results}

The characteristics of the patients are shown in Table 1 . The mean age of the subjects in the survey was $67 \pm 11$ years old (range: 37 to 88 years), mean BMI was $24.2 \pm 3.3 \mathrm{~kg} / \mathrm{m} 2$ (19.0 to $30.6 \mathrm{~kg} / \mathrm{m} 2$ ), and obesity assessed by BMI was normal, but 15 (41\%) subjects were considered to be obese based on BMI $\geq 25.0$ $\mathrm{kg} / \mathrm{m} 2$ and no subject was lean [13]. Mean SBP was $129 \pm 16$ $\mathrm{mmHg}$ (88 to $185 \mathrm{mmHg}$ ) and mean DBP was $73 \pm 10 \mathrm{mmHg}$ (44 to $109 \mathrm{mmHg}$ ), which is within the hypotensive goal for patients with CKD (SBP: $130 \mathrm{mmHg}$, DBP: $80 \mathrm{mmHg}$ ) [14].

The major primary disease was glomerulonephritis in 16 (43\%) subjects, followed by diabetic nephropathy in $11(30 \%)$, connective tissue disease in $6(16 \%)$, nephrotic syndrome in 4 (11\%), nephrosclerosis in $3(8 \%)$, and renal artery stenosis in 2 (5\%). The major complication was hypertension in 35 (95\%) subjects, followed by dyslipidemia and diabetes mellitus in 21 (57\%), hyperuricemia in 19 (51\%), and renal anemia 17 (46\%).

Diuretics were prescribed in 12 subjects (33\%) in spring, 12 (32\%) in summer, 11 (29\%) in autumn, and 10 (26\%) in winter; and all were given as monotherapy. Furosemide was prescribed in 4 subjects (11\%) in spring and $3(8 \%)$ in summer, autumn and winter. Azosemide was prescribed in $3(8 \%)$ in spring, summer and winter, and $2(5 \%)$ in autumn. Trichlormethiazide was prescribed in $3(8 \%)$ in spring, summer and autumn, and 2 (5\%) in winter. Blood and urine data determined at the beginning of survey are shown in Table 2.

Results for $24 \mathrm{hUV}$ and urinalysis by season are shown in Table 3. There was no significant difference in $24 \mathrm{hUV}$ and 
Table 1: Patients profile

\begin{tabular}{|l|l|l|l|l|l|l|}
\hline \multicolumn{7}{|c|}{ Total(n=37) } \\
\hline Age & (years old) & 67 & \pm & 11 & 88 & 37 \\
\hline Height & $(\mathrm{cm})$ & 164.1 & \pm & 6.7 & 174.5 & 152.0 \\
\hline Weight & $(\mathrm{kg})$ & 65.3 & \pm & 10.6 & 92.0 & 45.0 \\
\hline BMI & $\left(\mathrm{kg} / \mathrm{m}^{2}\right)$ & 24.2 & \pm & 3.3 & 30.6 & 19.0 \\
\hline SBP & $(\mathrm{mmHg})$ & 129 & \pm & 16 & 185 & 88 \\
\hline DBP & $(\mathrm{mmHg})$ & 73 & \pm & 10 & 109 & 44 \\
\hline
\end{tabular}

urinalysis between seasons. The mean $24 \mathrm{hUV}$ was $1785 \pm 491$ $\mathrm{mL} /$ day throughout the year, $1850 \pm 446 \mathrm{~mL} /$ day in spring, $1690 \pm 479 \mathrm{~mL} /$ day in summer, $1785 \pm 576 \mathrm{~mL} /$ day in autumn, and $1815 \pm 457 \mathrm{~mL} /$ day in winter. All these volumes were higher than the reference range of $1500 \mathrm{~mL} /$ day [15]. Mean Na throughout the year was $82 \pm 29 \mathrm{mEq} / \mathrm{L}$, within the reference range of $40-90$ $\mathrm{mEq} / \mathrm{L}$. Mean K throughout the year was $20.4 \pm 9.4 \mathrm{mEq} / \mathrm{L}$, which was also within the reference range of $20-60 \mathrm{mEq} / \mathrm{L}$ except in summer [16].

Results for $24 \mathrm{hUV}$ and urinalysis by season and adherence to the indicated $\mathrm{E}$ are shown in Table 4. There was no significant difference in $24 \mathrm{hUV}$ and urinalysis by season and adherence to indicated $\mathrm{E}$ among seasons. In comparison by adherence to the $\mathrm{E}$ indication, UN in Group A was $281 \pm 118 \mathrm{mg} / \mathrm{dL}$ in spring, $300 \pm 121$ $\mathrm{mg} / \mathrm{dL}$ in summer, $329 \pm 166 \mathrm{mg} / \mathrm{dL}$ in autumn, and $290 \pm 120 \mathrm{mg} /$ dL in winter, while UN in Group B was $429 \pm 169 \mathrm{mg} / \mathrm{dL}$ in spring $376 \pm 160 \mathrm{mg} / \mathrm{dL}$ in summer, $378 \pm 157 \mathrm{mg} / \mathrm{dL}$ in autumn, and $390 \pm 124 \mathrm{mg} / \mathrm{dL}$ in winter. Thus, UN in Group A was significantly lower in all seasons ( $\mathrm{p}<0.001)$. Similarly, urine K in Group A was all significantly lower than those in Group B. Variance of all was significantly higher in Group A than in Group B.

Results for $24 \mathrm{hUV}$ and urinalysis by season and adherence to the indicated Pro are shown in Table 5. There was no significant difference in $24 \mathrm{hUV}$ and urinalysis by season and adherence to Pro indication among seasons. In comparison by adherence to Pro indication, UN in Group A was significantly lower than those in Group B, and urine $\mathrm{Na}$ and $\mathrm{K}$ in Group A in all seasons were significantly lower than those in Group B. Variance of $24 \mathrm{hUV}$ in autumn was significantly higher in Group A than in Group B.

Results for $24 \mathrm{hUV}$ and urinalysis by season and adherence to indicated $\mathrm{NaCl}$ are shown in Table 6 . There was no significant difference in $24 \mathrm{hUV}$ and urinalysis by Season and adherence to $\mathrm{NaCl}$ indication among seasons. In comparison by adherence to $\mathrm{NaCl}$ indication, $\mathrm{UN}$, urine $\mathrm{Na}, \mathrm{K}$ in all seasons in Group A were significantly lower than those in Group B.
Table 2: Clinical laboratory data of the patients at registration

\begin{tabular}{|l|l|l|l|l|}
\hline & & \multicolumn{3}{|l|}{ Total(n=37) } \\
\hline & & M & \pm & SD \\
\hline RBC & $\left(\times 10^{2} / \mu \mathrm{L}\right)$ & 3.8 & \pm & 0.6 \\
\hline Hb & $(\mathrm{g} / \mathrm{dL})$ & 11.8 & \pm & 1.7 \\
\hline Ht & $(\%)$ & 35.0 & \pm & 4.8 \\
\hline WBC & $\left(\times 10^{3} / \mu \mathrm{L}\right)$ & 6.0 & \pm & 1.7 \\
\hline PLt & $\left(\times 10^{2} / \mu \mathrm{L}\right)$ & 200.7 & \pm & 72.0 \\
\hline TP & $(\mathrm{g} / \mathrm{dL})$ & 6.7 & \pm & 0.4 \\
\hline Alb & $(\mathrm{g} / \mathrm{dL})$ & 3.9 & \pm & 0.4 \\
\hline TC & $(\mathrm{mg} / \mathrm{dL})$ & 181 & \pm & 35 \\
\hline LDL-C & $(\mathrm{mg} / \mathrm{dL})$ & 97 & \pm & 25 \\
\hline FPG & $(\mathrm{mg} / \mathrm{dL})$ & 129 & \pm & 61 \\
\hline$\gamma-G T P$ & $(\mathrm{U} / \mathrm{L})$ & 29 & \pm & 18 \\
\hline BUN & $(\mathrm{mg} / \mathrm{dL})$ & 38.4 & \pm & 18.2 \\
\hline Cr & $(\mathrm{mg} / \mathrm{dL})$ & 3.22 & \pm & 1.88 \\
\hline UA & $(\mathrm{mg} / \mathrm{dL})$ & 7.0 & \pm & 1.3 \\
\hline eGFR & $\left(\mathrm{mL} / \mathrm{min} / 1.73 \mathrm{~m}^{2}\right)$ & 22 & \pm & 16 \\
\hline Na & $(\mathrm{mEq} / \mathrm{L})$ & 141 & \pm & 2 \\
\hline K & $(\mathrm{mEq} / \mathrm{L})$ & 4.7 & \pm & 0.6 \\
\hline Ca & $(\mathrm{mg} / \mathrm{dL})$ & 8.6 & \pm & 0.5 \\
\hline P & $(\mathrm{mg} / \mathrm{dL})$ & 3.7 & \pm & 0.7 \\
\hline Cr(spot urine) & $(\mathrm{mg} / \mathrm{dL})$ & 117 & \pm & 102 \\
\hline TP(spot urine) & & & \\
\hline & & 89.6 & \pm & 34.1 \\
\hline
\end{tabular}

\section{Discussion}

Seasonal variations of blood pressure, hematology, 24hUV and excreted urinary components and the relationship with adherence to diet therapy in patients with CKD were examined in this study. The mean age of the subjects was $67 \pm 11$ years old, and the accuracy of $24 \mathrm{hUV}$ in such elderly patients is likely to be low, which may cause errors in the results. However, the subjects measured 24hUV for 2 years or longer; therefore, they were a population with a good technique of urine collection with less error. There were no significant differences in blood pressure, hematology, urine volume, and urinalysis by season. These results show that the test data determined by $24 \mathrm{hUV}$ in patients with CKD were not influenced by seasonal variations.

There were seasonal variations of blood pressure, hematology, urine volume and urinalysis, and adherence to diet indication. For adherence to the energy indication, BUN, urine UN, K in Group A were significantly lower than those in Group B, and Na also showed a decreasing tendency. These results show that subjects with good adherence to the indicated energy had low excreted urinary components. Energy intake in Group B varied, which 
Table 3: 24hUV and urinalysis by season

\begin{tabular}{|l|l|l|l|l|}
$\operatorname{Total}(\mathrm{n}=37 \times 4)$ & Spring(n=37) & Summer(n=37) & Autumn(n=37) & Winter(n=37)
\end{tabular}

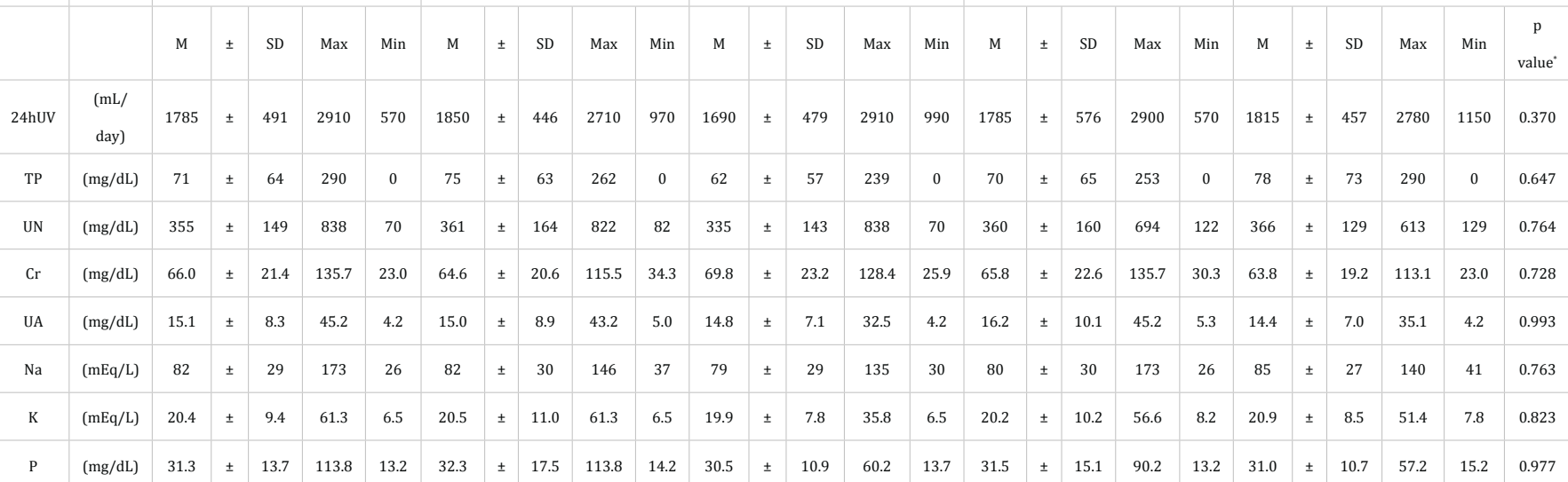

There was no significant difference (probability $<0.05$ ) in all measured items among 4 seasons

Table 4: $24 \mathrm{hUV}$ and urinalysis by season and adherence to the indicated energy

\begin{tabular}{|c|c|c|c|c|c|c|c|c|c|c|c|c|c|c|c|c|c|c|c|}
\hline & & \multirow{2}{*}{$\begin{array}{l}\text { Adherence } \\
\text { group }\end{array}$} & \multicolumn{3}{|c|}{$\operatorname{Total}(A=60 \quad B=88)$} & \multirow[b]{2}{*}{$\begin{array}{c}\text { pvalue } \\
*\end{array}$} & \multicolumn{3}{|c|}{$\begin{array}{l}\operatorname{Spring}(A=17 \\
B=20)\end{array}$} & \multicolumn{3}{|c|}{$\begin{array}{l}\text { Summer }(A=20 \\
B=17)\end{array}$} & \multicolumn{3}{|c|}{$\begin{array}{l}\text { Autumn }(A=14 \\
B=23)\end{array}$} & \multicolumn{3}{|c|}{$\begin{array}{l}\text { Winter }(A=9 \\
B=28)\end{array}$} & \multirow[b]{2}{*}{$\begin{array}{c}\text { pvalue } \\
*\end{array}$} \\
\hline & & & M & \pm & SD & & M & \pm & SD & M & \pm & SD & M & \pm & SD & M & \pm & SD & \\
\hline \multirow[t]{2}{*}{$24 \mathrm{hUV}$} & $\begin{array}{l}(\mathrm{mL} / \\
\text { day) }\end{array}$ & A & 1822 & \pm & 466 & \multirow[t]{2}{*}{0.368} & 2018 & \pm & 342 & 1680 & \pm & 462 & 1800 & \pm & 498 & 1804 & \pm & 566 & \multirow[t]{2}{*}{0.446} \\
\hline & & B & 1759 & \pm & 508 & & 1707 & \pm & 481 & 1702 & \pm & 512 & 1775 & \pm & 629 & 1819 & \pm & 429 & \\
\hline \multirow[t]{2}{*}{ UN } & $(\mathrm{mg} / \mathrm{dL})$ & A & 299.9 & \pm & 129.6 & \multirow{2}{*}{0.001} & 281 & \pm & 118 & 300 & \pm & 121 & 329 & \pm & 166 & 290 & \pm & 120 & \multirow{2}{*}{$<0.001$} \\
\hline & & B & 393.0 & \pm & 149.4 & & 429 & \pm & 169 & 376 & \pm & 160 & 378 & \pm & 157 & 390 & \pm & 124 & \\
\hline \multirow[t]{2}{*}{$\mathrm{Na}$} & $(\mathrm{mEq} / \mathrm{L})$ & A & 76 & \pm & 29 & \multirow{2}{*}{0.054} & 67 & \pm & 27 & 79 & \pm & 31 & 80 & \pm & 33 & 80 & \pm & 26 & \multirow{2}{*}{0.060} \\
\hline & & B & 85 & \pm & 28 & & 95 & \pm & 27 & 80 & \pm & 29 & 79 & \pm & 29 & 86 & \pm & 27 & \\
\hline \multirow[t]{2}{*}{$\mathbf{K}$} & $(\mathrm{mEq} / \mathrm{L})$ & A & 17.1 & \pm & 6.8 & \multirow{2}{*}{0.001} & 16.4 & \pm & 7.7 & 17.5 & \pm & 7.3 & 18.6 & \pm & 6.1 & 15.5 & \pm & 4.9 & \multirow{2}{*}{$<0.001$} \\
\hline & & B & 22.6 & \pm & 10.3 & & 24.0 & \pm & 12.3 & 22.7 & \pm & 7.7 & 21.1 & \pm & 12.0 & 22.7 & \pm & 8.7 & \\
\hline
\end{tabular}

* express comparison between A and B

Table 5: $24 \mathrm{hUV}$ and urinalysis by season and adherence to the indicated protein intake

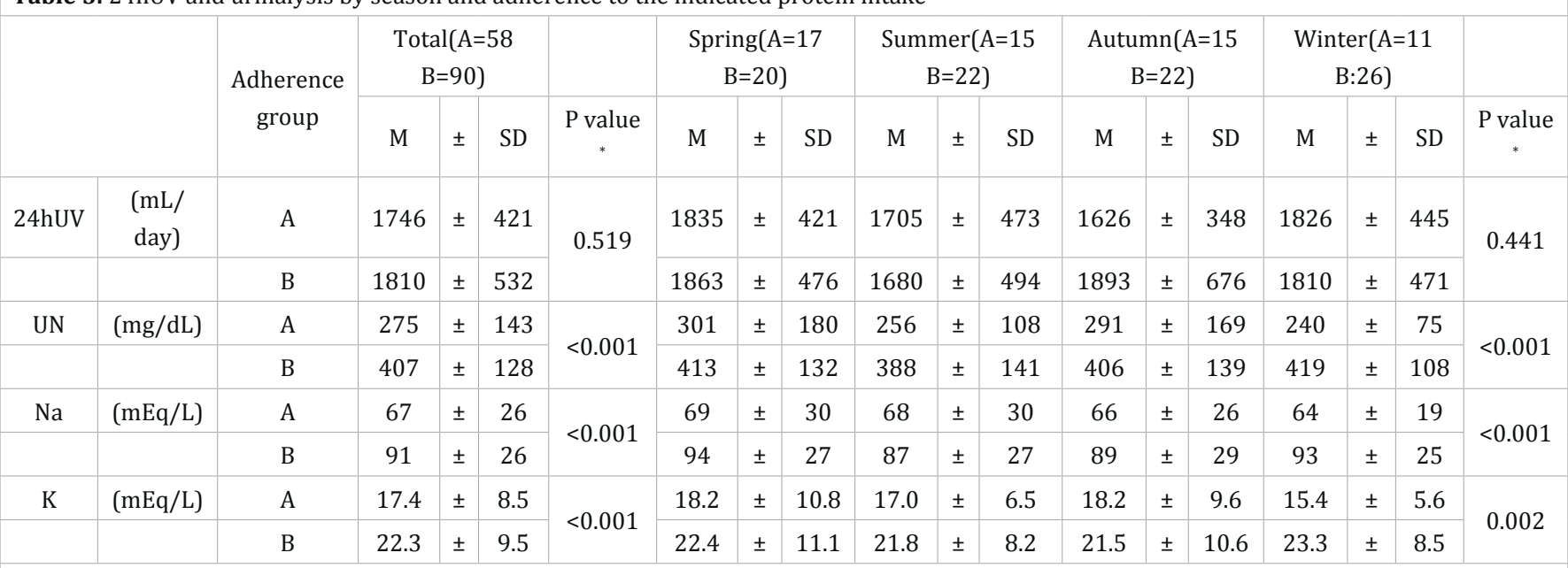

* express comparison between $\mathrm{A}$ and $\mathrm{B}$

Citation: Kanno H, Onda R, Nagaoka Y, Miyaoka Y, Okada T, et al. (2019) Seasonal Variation of Nutritional Intake from 24-Hour Urine Collection and Adherence in Patients with Chronic Kidney Disease. J Nutrition Health Food Sci 7(4):1-9. D0I: 10.15226/ 


\begin{tabular}{|c|c|c|c|c|c|c|c|c|c|c|c|c|c|c|c|c|c|c|c|}
\hline & & \multirow[t]{2}{*}{$\begin{array}{c}\text { Adherence } \\
\text { group }\end{array}$} & \multicolumn{3}{|c|}{$\begin{array}{c}\text { Total }(A=58 \\
\text { B:90) }\end{array}$} & \multirow[b]{2}{*}{$\begin{array}{c}\mathrm{p} \\
\text { value * }\end{array}$} & \multicolumn{3}{|c|}{$\begin{array}{c}\text { Spring }(A=12 \\
B=25)\end{array}$} & \multicolumn{3}{|c|}{$\begin{array}{c}\text { Summer( } A=18 \\
B=19)\end{array}$} & \multicolumn{3}{|c|}{$\begin{array}{c}\text { Autumn }(A=16 \\
B=21)\end{array}$} & \multicolumn{3}{|c|}{$\begin{array}{c}\text { Winter }(A=12 \\
B=25)\end{array}$} & \multirow[b]{2}{*}{$\mathrm{p}$ value } \\
\hline & & & M & \pm & SD & & M & \pm & SD & M & \pm & SD & M & \pm & $\mathrm{SD}$ & M & \pm & SD & \\
\hline \multirow[t]{2}{*}{$24 \mathrm{hUV}$} & $\begin{array}{l}(\mathrm{mL} / \\
\text { day) }\end{array}$ & A & 1744 & \pm & 450 & 0.421 & 1932 & \pm & 394 & 1658 & \pm & 480 & 1758 & \pm & 540 & 1669 & \pm & 286 & 0.425 \\
\hline & & B & 1811 & \pm & 516 & & 1811 & \pm & 472 & 1721 & \pm & 489 & 1805 & \pm & 613 & 1885 & \pm & 510 & \\
\hline \multirow[t]{2}{*}{ UN } & $(\mathrm{mg} / \mathrm{dL})$ & A & 269 & \pm & 114 & $<0.001$ & 255 & \pm & 122 & 277 & \pm & 123 & 259 & \pm & 119 & 282 & \pm & 95 & $<0.001$ \\
\hline & & B & 411 & \pm & 142 & & 412 & \pm & 158 & 389 & \pm & 142 & 436 & \pm & 146 & 406 & \pm & 125 & \\
\hline \multirow[t]{2}{*}{$\mathrm{Na}$} & $(\mathrm{mEq} / \mathrm{L})$ & A & 64 & \pm & 25 & $<0.001$ & 60 & \pm & 24 & 66 & \pm & 29 & 61 & \pm & 23 & 71 & \pm & 24 & $<0.001$ \\
\hline & & B & 93 & \pm & 25 & & 93 & \pm & 27 & 92 & \pm & 24 & 94 & \pm & 26 & 91 & \pm & 25 & \\
\hline \multirow[t]{2}{*}{ K } & $(\mathrm{mEq} / \mathrm{L})$ & A & 16.8 & \pm & 6.7 & $<0.001$ & 14.3 & \pm & 5.9 & 18.4 & \pm & 7.9 & 15.7 & \pm & 5.4 & 18.1 & \pm & 7.2 & $<0.001$ \\
\hline & & B & 22.7 & \pm & 10.1 & & 23.5 & \pm & 11.7 & 21.2 & \pm & 7.7 & 23.6 & \pm & 11.7 & 22.3 & \pm & 8.9 & \\
\hline
\end{tabular}

*express comparison between A and B

suggests that these subjects mixed excessive and low energy intake. Consequently, there was no significant difference in energy intake between Groups A and B.

For adherence to protein indication, WBC, BUN, TC, LDL-C, UP, UN, UA, Na, K and P in Group A were significantly lower than those in Group B. These results show that good adherence to the indicated protein kept excreted urinary components low. Protein intake in Group A was significantly lower than that in Group B ( $34 \pm 8$ vs. $51 \pm 11 \mathrm{~g} /$ day). Thus, protein intake in Group $\mathrm{B}$ was excessive, which led to high BUN, UN, K and P. There was no significant difference in urine $\mathrm{Cr}$ by adherence to protein indication. An increase or decrease in urine $\mathrm{Cr}$ does not depend on diet or urine volume, but urine $\mathrm{Cr}$ is proportional to muscle development and momentum [13]. However, these results show that $\mathrm{Cr}$ is independent of protein intake.

For adherence to the salt indication, WBC, BUN, TC, LDL-C, UP, UN, UA, Na, K and P in Group A were significantly lower than those in Group B. These results show that good adherence to the salt indication maintained a low level of excreted urinary components. It is notable that items with a significant difference between Groups A and B by adherence to the salt indication were almost the same as those by adherence to the protein indication. In healthy subjects, energy correlates strongly with salt intake and there is a relationship between salt and protein intake [14]. Based on these results, good adherence to protein indication appears to be proportional to that for salt indication, leading to similar results for excreted urine components.

The results of this study show that blood pressure, hematology, 24hUV and urinalysis in patients with CKD did not show seasonal variations, and it suggested diet intake of the subjects were stable throughout year. Healthy subjects have seasonal variety of food intake in daily life, but nutrients except vitamin $\mathrm{C}$ and iron have no seasonal variation [15]. Diet intake may effect on urine volume by amount of water intake, but water intake obtained from diet in healthy elderly people has been shown not to change in summer and winter $[16,17]$. Subjects in Group A were in compliance with the dietary indication and the mean age was $67 \pm 11$ years old; therefore, seasonal variations due to diet appeared to be few, similarly to the results of the previous study. The subjects in this study were given nutrition education continuously for 2 years or more, and this may have kept a stable dietary intake, leading to less seasonal variation. Dietary intake in Group A was close to the indication throughout the year. Based on the above, 24hUV in patients who maintain appropriate diet therapy shows accurate dietary contents.

A several limitations are considered in this study. First, the patients recruited in this study were well-trained to our procedure to $24 \mathrm{~h}$ urine collection. Therefore, the present results may not be applied to the general patients. Secondly season was defined by calendar month. Temperature and humidity that relate much to sweating were not considered in data analysis.

\section{Conclusion}

This study was conducted to examine seasonal variations of blood pressure, hematology, 24hUV, excreted urinary components, and their relation with adherence to diet therapy in patients with CKD. The results showed that blood pressure, hematology, urine $24 \mathrm{hUV}$ and urinalysis were not influenced by seasonal variations, and these findings were due to the influence of diet. In patients with CKD who require diet therapy, diet is stable throughout the year, and consequently, urine volume and excreted urinary components showed no seasonal variations. On the other hand, some hematology items depended on adherence to diet therapy, and these results in Group A with good adherence were significantly lower than those in Group BC. Dietary intake in Group A was close to the diet indication throughout the year. Based on these findings, hematology determined by $24 \mathrm{hUV}$ in patients who maintain an appropriate diet gives accurate dietary contents. 


\section{Funding Statement}

No financial grants and other funding to be disclosed.

\section{Acknowledgement}

We wish to express our appreciation to Miho Inoue, Haruka Kudo, and Chie Miyata, Kagawa Nutrition University, for their supports in data processing.

\section{References}

1. Kaysen GA, Odabaei G. Dietary protein restriction and preservation of kidney function in chronic kidney disease. Blood Purif. 2013;35(13):22-25.

2. Koppe L, Fouque D. The Role for Protein Restriction in Addition to Renin-Angiotensin-Aldosterone System Inhibitors in the Management of CKD. Am J Kidney Dis. 2019;73(2):248-257. Doi:10.1053/j. ajkd.2018.06.016

3. Inker LA, Astor BC, Fox CH, Isakova T, Lash JP, Peralta CA, et al. KDOQI US commentary on the 2012 KDIGO clinical practice guideline for the evaluation and management of CKD. Am J Kidney Dis. 2014;63(5):713735. Doi: 10.1053/j.ajkd.2014.01.416

4. Garofalo C, Borrelli S, Provenzano M, De Stefano T, Vita C, Chiodini P, et al. Dietary Salt Restriction in Chronic Kidney Disease: A Meta-Analysis of Randomized Clinical Trials. Nutrients. 2018;10(6): pii: E732. doi: $10.3390 /$ nu10060732

5. Black AE, Welch AA, Bingham SA. Validation of dietary intakes measured by diet history against $24 \mathrm{~h}$ urinary nitrogen excretion and energy expenditure measured by the doubly-labelled water method in middle-aged women. Br J Nutr. 2000;83(4):341-354. doi: 10.1017/ s0007114500000441

6. Kawasaki T, Itoh K, Uezono K, Sasaki H. A simple method for estimating $24 \mathrm{~h}$ urinary sodium and potassium excretion from second morning voiding urine specimen in adults. Clin Exp Pharmacol Physiol. 1993;20(1):7-14. doi: 10.1111/j.1440-1681.1993.tb01496.x

7. Evidence-based Clinical Practice Guideline for CKD 2013. Clin Exp Nephrol. 2014;18(3):346-423.
8. Peleg AY, Hooper DC. Hospital-acquired infections due to gramnegative bacteria. N Engl J Med. 2010;362(19):1804-1813. doi: 10.1056/NEJMra0904124

9. Bountziouka V, Panagiotakos DB. Statistical methods used for the evaluation of reliability and validity of nutrition assessment tools used in medical research. Curr Pharm Des. 2010;16(34):3770-3775.

10. Ji C, Sykes L, Paul C, Dary O, Legetic B, Campbell NR, et al. Systematic review of studies comparing 24-hour and spot urine collections for estimating population salt intake. Rev Panam Salud Publica. 2012;32(4):307-315.

11. Buono MJ, Ball KD, Kolkhorst FW. Sodium ion concentration vs. sweat rate relationship in humans. J Appl Physiol. 2007;103(3):990-4. doi: 10.1152/japplphysiol.00015.2007

12. Agency JM. Weather, Climate \& Earthquake Information. Japan Meteorological Agency.

13. Heymsfield SB, Arteaga C, McManus C, Smith J, Moffitt S. Measurement of muscle mass in humans: validity of the 24-hour urinary creatinine method. Am J Clin Nutr. 1983;37(3):478-494. doi: 10.1093/ ajcn/37.3.478

14. Jia Jiet $\mathrm{L}$, Soma R M. High salt diets in young university adults and the correlation with blood pressure, protein intake and fat free mass. Bioscience Horizons: The International Journal of Student Research. 2017; 10:hzx003-hzx.

15. Ishihara J, Sobue T, Yamamoto S, Yoshimi I, Sasaki S, Kobayashi M, et al. Validity and reproducibility of a self-administered food frequency questionnaire in the JPHC Study Cohort II: study design, participant profile and results in comparison with Cohort I. J Epidemiol. 2003;13;( 1Suppl):S134-S47.

16. An R, McCaffrey J. Plain water consumption in relation to energy intake and diet quality among US adults, 2005-2012. J Hum Nutr Diet. 2016;29(5):624-632. doi: 10.1111/jhn.12368

17. Tani Y, Asakura K, Sasaki S, Hirota N, Notsu A, Todoriki H, et al. The influence of season and air temperature on water intake by food groups in a sample of free-living Japanese adults. Eur J Clin Nutr. 2015;69(8):907-13. doi: 10.1038/ejcn.2014.290 